\title{
Köyceğiz Gölü Su ve Taban Sedimanlarının Sıcaklık Dağılımı
}

\author{
Distribution of Water and Bottom Sediment Temperature of Lake Köyceğiz \\ Özgür AVŞAR D, Bedri KURTULUŞ D \\ Muğla Sitkı Koçman Üniversitesi, Jeoloji Mühendisliği Bölümü, Menteşe, MUĞLA
}

Geliş (Received): 4 Temmuz (July) 2017, Düzeltme (Revised): 5 Ağustos (August) 2017, Kabul (Accepted): 11 Ağustos (August) 2017

\section{ÖZ}

Köyceğiz Gölü, 52 km² yüzölçümüyle Türkiye'nin en büyük 16. gölüdür. Yapılan öncel çalışmalar bu gölün meromiktik karakterde olduğunu ortaya koymaktadır. Bu çalışma kapsamında, 40 adet noktada CTD ve termoprob cihazlarıyla Nisan ayında ölçümler yapılmış, göl suyu sıcaklığının uzaysal dağılımı ile taban sedimanlarının sıcaklığının alansal dağılımı detaylı bir şekilde araştırılmıştır. Su gözlem noktalarında elektriksel iletkenlik ve pH ölçümlerini de içeren incelemede, gölde, fiziksel özellikleri birbirinden farklı dört adet su kütlesinin olduğu tespit edilmiştir. Kuzey ve güney çanaktaki su ile taban sedimanı sıcaklıkları karşılaştırıldığında, gölün kuzey çanağında daha soğuk olduğu gözlemlenmiştir. Ayrıca, bazı sualtı kaynaklarının, çevresindeki su ve sedimanların sıcaklığını artırdığı belirlenmiştir.

Anahtar Kelimeler: Meromiktik, Sualtı Jeotermal Kaynak, Termal Tabakalanma, Termoprob, Uzaysal Dağılım.

\begin{abstract}
With its $52 \mathrm{~km}^{2}$ areal extent, the Lake Köyceğiz is the $16^{\text {th }}$ largest lake in Turkey. As it is indicated in the earlier studies, the lake is meromictic. Within the scope of this study, thermoprobe and CTD measurements were done in April covering 40 locations and spatial distribution of the lake water temperature and the areal distribution of the lake bottom sediments were investigated in detail. Investigations including electrical conductivity and $p H$ measurements at water monitoring locations show that there are physically four distinct water bodies in the Lake Köyceğiz. The water and sediment temperatures in northern basin are slightly less than the southern basin. In addition, subaqueous springs increase the temperature of the water and sediment, and create a positive temperature anomaly around these locations.
\end{abstract}

Keywords: Meromictic, Subaqueous Geothermal Spring, Thermal Stratification, Thermoprobe, Spatial Distribution. 
Avşar, Kurtuluş

\section{GIIRIŞ}

Göllerle ilgili çalışmalarda suyun sıcaklık, $\mathrm{pH}$ ve EC gibi özelliklerinin ölçülmesi ve değerlendirilmesi limnoloji çalışmalarının ilk adımını oluşturmaktadır. Bu ölçümler uzun yıllar elle ve basit ölçüm cihazları ile yapılmıştır. Son yıllarda yüksek frekaslı ölçüm cihazlarının gelişmesiyle birlikte yapılan ölçümlerin zaman aralıkları ve miktarı artmış, bu ölçümler nispeten küçük cihazlarda depolanabilmiştir.

Güneybatı Anadolu'da bulunan Köyceğiz Gölü 52 km² alanıyla Türkiye'nin en büyük 16 . gölüdür. Gölün sıra dışı kimyasal ve fiziksel özellikleri birçok araştırmacının ilgisini çekmiş, limnolojik ve çevresel özelliklerini inceleyen önemli çalışmalar yapılmıştır (Kazancı vd., 1992; Ertürk, 2002; Ertürk vd., 2014; Ertürk vd., 2017). Köyceğiz Gölü'ndeki en kapsamlı çalışmayı Bayarı vd. (1995) gerçekleştirmiştir. Göl suyu sıcaklığının ölçümü yanında eco-sounding tekniği ile taban sedimanlarını görüntülemişler, göl tabanından geçen fayları tespit etmişlerdir. $\mathrm{Bu}$ araştırmanın sonucunda Bayarı vd. (1995), gölün meromitik bir göl olduğu, yüzeyden 10 $\mathrm{m}$ derinlikte bir "termoklin" olduğu ve daha derinde oksijensiz, durgun, ölü bir su kütlesinin bulunduğu sonucuna varmışlardır. Yaptıkları su bütçesinden, gölü besleyen sicak ve soğuk su kaynaklarının olduğunu belirtmişler, hatta bazı su çıkışlarını jeofizik çalışmalarla ve sualtı akım ölçümleriyle tespit edebilmişlerdir. Köyceğiz Gölü ile ilgili yapılan bir diğer çalışma Kazancı ve Girgin (2001) tarafindan gerçekleştirilmiştir. Kazanc1 ve Girgin (2001), Köyceğiz ve Dalaman'daki 5 adet termal kaynakta su kimyası ve yosun çeşitliliği üzerine çalışma yapmış ve bu sahaların korunması gerektiğini savunmuştur. Köyceğiz Gölü'nde, Avşar vd. (2017) yaptıkları detaylı çalışmada, gölde 2 adet sualtı soğuk su kaynağ1 ve 3 adet sualtı sıcak su kaynağ tespit etmişlerdir. Avşar vd. (2016)'nın, göl çökellerinden aldıkları karot örnekleri üzerinde yaptıkları çalışmada, 370 yıllık varv kayıtlarına rastlanmış, bu kayıtlar tarihsel depremlerle ilişkilendirilerek bölgenin depremselliği ile ilgili önemli sonuçlara ulaşı1mıştır.

$\mathrm{Bu}$ çalışmanın amacı, yüksek frekanslı sıcaklık ölçüm cihazları kullanarak, Köyceğiz Gölü'nün su sıcaklığını ve taban çökellerinin sıcaklığının alansal dağılımını belirlemektir. $\mathrm{Bu}$ amaçla, 40 noktada düşey sicaklık profilleri ve taban çökel sıcaklıkları noktasal olarak ölçülmüştür. Çalışmada, gölün su sıcaklığına ek olarak pH ve EC değerleri yüksek çözünürlüklü bir şekilde ölçülmüş ve gölün fizikokimyasal modeli ortaya konmuştur. Öncel çalışmalarda her ne kadar kabaca gölün su sıcaklık dağılımı çıkarılsa da, bu çalışmada olduğu gibi detaylı bir sicaklık (pH ve EC) ölçümü daha önce yapılmamıştır. Termoprob isimli cihaz ile taban sediman sıcaklığının 40 noktada ölçülmesi, taban sedimanlarının sıcaklık dağılımı ile ilgili önemli bilgilere ulaşılmasını sağlamıştır.

\section{ÇALIŞMA ALANI}

Yukarıda belirtildiği gibi, yaklaşık 52 $\mathrm{km}^{2}$ alanıyla Köyceğiz Gölü, Türkiye'nin en büyük ilk 20 gölü arasında yer almaktadır. 10 km uzunluğundaki Dalyan kanalı ile Akdeniz'e bağlanan göl "Köyceğiz-Dalyan Havzası Özel Çevre Koruma Bölgesi" adıyla devlet tarafindan koruma altına alınmıştır. Ender bulunan ekolojik yapıs1, bölgeyi koruma altına alınmaya değer kılmıştır. Bölgede tipik Akdeniz iklimi hakimdir. Yazları sıcak ve kurak, kışları 1lık ve yağışlıdır. Kuzeyde ve güneyde iki çanaktan oluşan gölün kuzeydeki en derin yeri $25 \mathrm{~m}$, güneydeki ise 32 m'dir. Bu iki çanak D-B uzanımlı, su derinliğinin 2-3 metreye düştüğü bir sırt ile ayrılmaktadır. Öncel çalışmalar, göl suyunun yüzeyin $10 \mathrm{~m}$ altından tabana kadar olan derinlikte soğuk, 
oksijensiz, ölü bir su kütlesinin olduğunu göstermiştir (Bayarı vd., 1995; Kazancı ve Girgin, 2001).

İnceleme alanının üzerinde bulunduğu Güneybatı Anadolu, birçok bilimsel araştırmaya konu olmuştur. Genellikle jeolojik oluşum süreçleri üzerine teoriler üreten bu araştırmalar, bölgenin oluşum tarihçesi, jeolojik birimlerin tanımlanması ve birbirine göre konumları ile ilgili çok değerli ve detaylı bilgiler sunmaktadır (Rimmelé, vd., 2003a; 2003b, Ten Veen vd., 2009; Hinsbergen, 2010; Hinsbergen vd., 2010; Sözbilir vd., 2011). Bu çalışmada, Şenel (1997) tarafından hazırlanan 1/100000 ölçekli jeoloji haritası sadeleştirilerek Şekil 1'de sunulmuştur. İnceleme alanının tamamında Likya napları olarak bilinen allokton birimler yüzlek vermektedir (Şekil 1). Kuvaterner alüvyon bütün birimleri uyumsuz olarak üzerlemektedir. Likya napları, adından da anlaşılacağı üzere, sınırında düşük açılı bindirme fayları olan nap birimlerinin üst üste istiflenmesiyle oluşmuştur. Likya napları kaba olarak peridotit (Marmaris Nap1) ve neritik/ pelajik karbonatlar (Gülbahar, Tavas ve Bodrum Napları) olarak iki ayrı alt birime ayrılmıştır (Şenel, 1997; Gökgöz ve Tarcan, 2006).

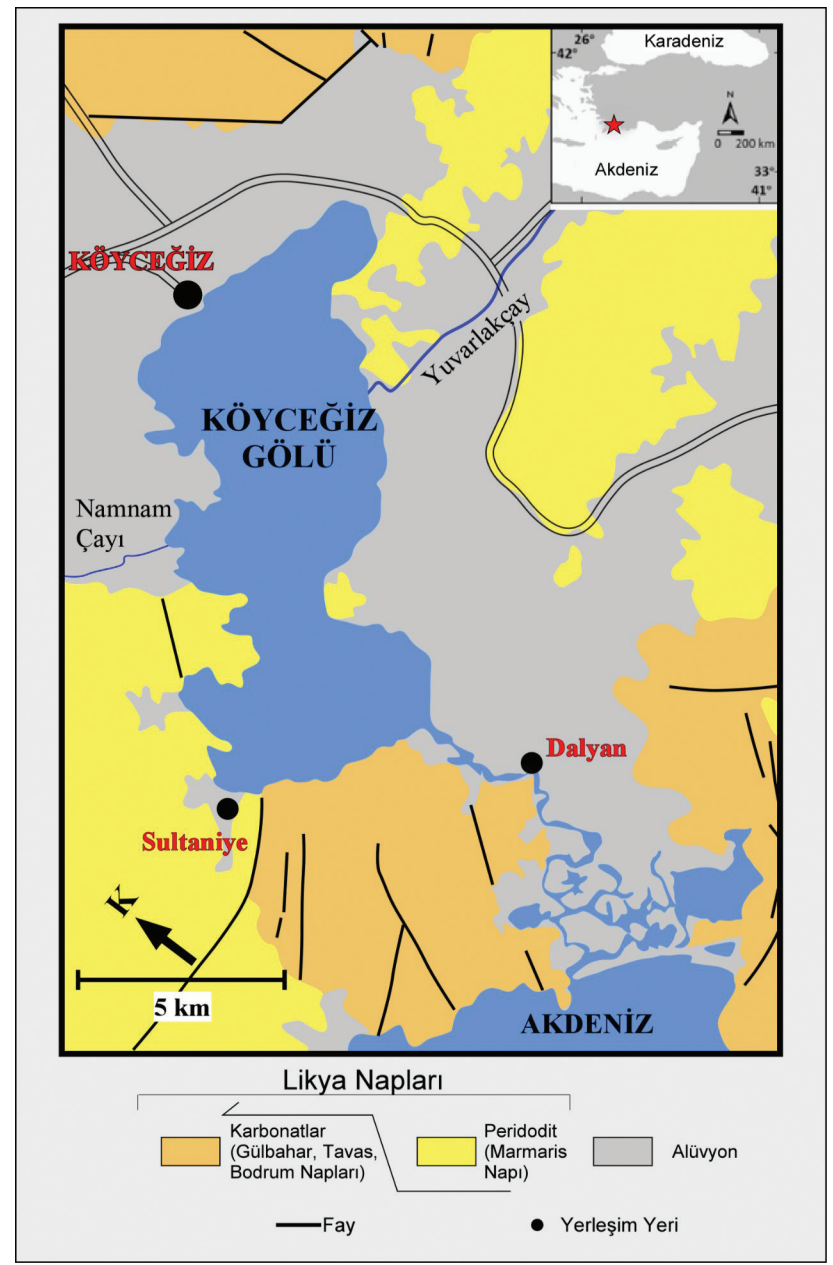

Şekil 1. Köyceğiz gölü çevresi jeoloji haritası (Şenel, 1997).

Figure 1. Geological map of the Lake Köyceğiz and its vicinity (Şenel, 1997). 
Avşar, Kurtuluş

Sahanın yapısal jeolojisi paleotektonik döneme ait bindirmeler ve aktif normal faylarla karakterize olmuştur. Erken Eosen Erken Oligosen dönemi boyunca etkin olan sıkışma tektoniği nap sisteminin oluşmasına neden olurken, Geç Miyosen ile başlayan ve etkisi günümüze kadar devam eden gerilme tektoniği güncel normal fayların ve horst graben sistemlerinin oluşmasına neden olmaktadır (Bozkurt ve Park, 1999; Rimmelé vd., 2003a; 2003b). Bindirme fayları ile birbirinden ayrilan jeolojik formasyonlarla ve bunları kesen daha genç normal faylarla morfolojisi şekillenen sahada, jeotermal sistemlerin gelişimi, bu yapısal jeoloji ile kontrol edilmektedir.

\section{MATERYAL VE YÖNTEM}

Bu çalışma, göl suyunun sıcaklık, pH ve EC değerlerinin belirlenmesinden (Multiparametre Ölçüm Cihazı) ve taban sedimanlarının sıcaklık ölçümlerinden (Termoprob Cihazı) oluşmaktadır. 2017 yılının Nisan ayında yapılan arazi çalışmaları 3 gün sürmüştür. Söz konusu çalışmada 10 m uzunluğunda bir tekne kiralanmış ve 40 noktada ölçümler yapılmıştır.

\section{Su Ölçümleri}

Köyceğiz göl suyunun üç boyutlu değerlendirilebilmesi için, YSI marka (6600) Multiparametre Ölçüm Cihazı ile, 2 saniyede bir ölçüm yapacak şekilde sicaklık, pH ve EC değerleri belirlenmiştir. Göl alanına düzgün dağılacak şekilde 40 adet noktada düşey ölçüm yapılmıştır. Çalışma boyunca koordinatları kaydetmek amacı ile (2 saniye aralıkla) Garmin marka (421S) Küresel Konumlandırma Cihazı (GPS) kullanılmıştır. Ölçüm yapılması planlanan noktaların koordinatları GPS'e kaydedilmiş, hedef noktaya varıldığında ipin ucuna bağlanan prob gölün tabanına doğru indirilip geri çekilerek düşey sicaklık, pH ve EC ölçümleri yapılmıştır. $\mathrm{Bu}$ üç parametreye ek olarak, su derinliğini de ölçen Multiparametre Ölçüm Cihazı, bu parametrelerin derinlikle değişiminin incelenebileceği profillerin oluşturulmasını da sağlamıştır. Ölçüm noktalarının (40 adet) dağılımı ve derinlikleri ( $1.7 \mathrm{~m}$ ile $31.9 \mathrm{~m}$ arasında) göz önünde bulundurulduğunda; sıcaklık, $\mathrm{pH}$ ve EC değerlerinin, tüm göl yüzeyini temsil edecek şekilde belirlendiği söylenebilir. Bu yaklaşım, bir noktada derinlemesine ölçüm değerlerini, yüzeyde yatay olarak yapılan ölçümlerle karşılaştırma olanağı sağlamıştır.

Sicaklık, EC ve pH verilerinin, Amerika Birleşik Devletleri Çevre Koruma Ajansı (EPA) bünyesinde yürütülen Çevresel Teknolojiler Verifikasyon Programı (ETV) kapsamında belgelenen aletsel ölçüm hata miktarları sırasıyla $\pm 0.15{ }^{\circ} \mathrm{C}, \pm \% 5, \pm 0.2$ birimdir. Çalışmalarda, ölçümlere yönelik kalite kontrol ölçümleri yapılmamıştır.

\section{Taban Çökel Sıcaklığı Ölçümleri}

Çalışma alanında, taban çökellerinin sıcaklığını ölçmek için Termoprob Cihazı kullanılmıştır. Termoprob, kromdan imal edilmiş, $2 \mathrm{~m}$ boyunda, $3.2 \mathrm{~cm}$ çapında sivri uçlu silindirik bir çubuktur. Kazık şeklindeki bu çubuğun içinde uca doğru bulunan bir hazneye Onset marka (HOBO) yüksek frekanslı sıcaklık ölçüm cihazı yerleştirilmiştir. Termoprob, üstüne bağlanan bir iple, göl tabanına 2-3 metre kalana kadar indirilir ve bu yükseklikten bırakılarak tabana saplanması sağlanır. Tabana saplanmış olarak 5-6 dakika bekledikten sonra yüzeye çekilir. Kazığın içindeki silindirik ölçüm cihazı, tüp şeklindeki haznenin içinde, tabana çarpmada ve saplanmada oluşabilecek titreşimden zarar görmemesi için önünden ve arkasından yayla desteklenmiştir. 
Cihaz, saniyede bir sicaklık ölçüp kaydetmeye ayarlanmıştır. Hafizası 12 saat ölçüm yapmaya uygundur. 5-6 dakikalık bekleme, çamura en az 1 metre saplanmış olan Termoprob'un çevre sıcaklığını algılaması için yeterli bir süredir. Zamanı ve sıcaklığı saniyede bir ölçüp kaydeden cihazın, tabana saplanmış vaziyette kaldığ sürenin başlangıcı ve sonu çalışma defterine kaydedilir. Cihazdan kişisel bilgisayara indirilen zamana karşılık sıcaklık verilerinden, istenilen zaman aralığındaki veri, o noktanın verisi olarak kaydedilir. 5-6 dakikalık ölçüm sırasında okunan sicaklık, göl taban sedimanının o noktada, o andaki sıcaklığı olarak kaydedilir. Bulunan bu sicaklık değerleri, göl boyunca taban sediman sıcaklık dağılım haritasının oluşturulmasında kullanılmıştır. Bütün dağılım haritaları ve kesitler, Surfer 10 (Golden Software Inc., 2012) bilgisayar programında hazırlanmıştır.

Elde edilen su ve taban sedimanı ölçüm değerleri (Çizelge 1) kullanılarak dağılım haritaları oluşturulmuştur. Ayrıca, gölden alınan 3 adet kesit üzerinde; göl suyuna ait sıcaklık, pH ve EC dağılımı ve taban sicaklık değişimi gösterilmiştir. Bu veriler 1şı̆̆ında gölün fizikokimyasal dinamiğini anlamaya yönelik yaklaşımlar geliştirilmiştir.

Çizelge 1. Köyceğiz gölünde yapılan ölçümlerle ilgili genel bilgiler.

Table 1. General information about the measurements done in the Lake Köyceğiz.

\begin{tabular}{|c|c|c|c|c|c|c|c|c|c|}
\hline & $\begin{array}{l}\text { Ölçüm } \\
\text { Noktası }\end{array}$ & $\begin{array}{r}\text { Koo } \\
\text { (UTM }\end{array}$ & $\begin{array}{l}\text { dinat } \\
\text { NGS84) }\end{array}$ & $\begin{array}{c}\text { Su } \\
\text { Derinliği } \\
\text { (m) }\end{array}$ & $\begin{array}{l}\text { Ölçüim } \\
\text { Tarihi }\end{array}$ & $\begin{array}{c}\text { Yüzey Suyu } \\
\text { Sıcaklığı }\left({ }^{\circ} \mathbf{C}\right)\end{array}$ & $\begin{array}{c}\text { Taban Suyu } \\
\text { Sicaklığı }\left({ }^{\circ} \mathbf{C}\right)\end{array}$ & $\begin{array}{c}\text { Çamur } \\
\text { Sicaklık } \\
\left({ }^{\circ} \mathrm{C}\right)\end{array}$ & $\begin{array}{l}\text { Su çamur } \\
\text { sıcaklık } \\
\text { farkı }\left({ }^{\circ} \mathrm{C}\right)\end{array}$ \\
\hline 1 & K1 & 649660 & 4090803 & 19.959 & 09.04 .2017 & 18.78 & 12.67 & 15.008 & 2.338 \\
\hline 2 & $\mathrm{~K} 2$ & 651100 & 4090197 & 18.741 & 09.04 .2017 & 18.93 & 12.54 & 14.888 & 2.348 \\
\hline 3 & K3 & 652167 & 4089873 & 15.546 & 09.04 .2017 & 18.71 & 12.18 & 14.505 & 2.325 \\
\hline 4 & K5 & 653227 & 4089755 & 10.630 & 09.04 .2017 & 19.02 & 11.76 & 14.768 & 3.008 \\
\hline 5 & K6 & 650566 & 4088869 & 22.994 & 09.04 .2017 & 17.20 & 13.07 & 15.199 & 2.129 \\
\hline 6 & K7 & 649905 & 4089654 & 24.619 & 09.04 .2017 & 16.55 & 13.43 & 15.079 & 1.649 \\
\hline 7 & K8 & 648680 & 4090069 & 22.374 & 09.04 .2017 & 15.71 & 12.92 & 15.079 & 2.159 \\
\hline 8 & K9 & 649036 & 4089123 & 24.146 & 09.04 .2017 & 17.89 & 13.39 & 15.247 & 1.857 \\
\hline 9 & K10 & 649480 & 4088373 & 23.083 & 09.04 .2017 & 16.67 & 12.95 & 15.031 & 2.081 \\
\hline 10 & K11 & 650516 & 4087689 & 22.081 & 09.04 .2017 & 18.20 & 12.69 & 15.127 & 2.437 \\
\hline 11 & K12 & 649519 & 4087243 & 10.290 & 29.04 .2017 & 20.04 & 12.77 & 14.553 & 1.783 \\
\hline 12 & K13 & 648495 & 4087675 & 22.108 & 29.04 .2017 & 20.04 & 13.34 & 15.031 & 1.691 \\
\hline 13 & K14 & 648261 & 4088538 & 22.583 & 29.04 .2017 & 20.11 & 13.50 & 15.199 & 1.699 \\
\hline 14 & K15 & 647209 & 4087482 & 20.574 & 29.04 .2017 & 20.04 & 12.77 & 15.079 & 2.309 \\
\hline 15 & K16 & 648322 & 4086833 & 18.117 & 29.04 .2017 & 20.14 & 13.16 & 14.888 & 1.728 \\
\hline 16 & K17 & 649044 & 4086125 & 4.037 & 29.04 .2017 & 20.06 & 19.41 & 18.414 & -0.996 \\
\hline 17 & K18 & 647869 & 4085559 & 4.187 & 29.04 .2017 & 20.18 & 19.76 & 18.247 & -1.513 \\
\hline 18 & K19 & 647334 & 4086400 & 17.739 & 29.04 .2017 & 20.14 & 12.87 & 14.864 & 1.994 \\
\hline 19 & K20 & 646065 & 4086861 & 15.079 & 29.04 .2017 & 20.21 & 13.37 & 14.745 & 1.375 \\
\hline 20 & K21 & 646513 & 4085863 & 4.852 & 29.04 .2017 & 20.39 & 20.13 & 17.748 & -2.382 \\
\hline 21 & K22 & 645274 & 4085535 & 4.401 & 29.04 .2017 & 20.49 & 19.30 & 17.439 & -1.861 \\
\hline 22 & K23 & 645732 & 4084839 & 3.360 & 29.04 .2017 & 20.34 & 19.89 & 18.224 & -1.666 \\
\hline 23 & K24 & 645300 & 4083755 & 5.173 & 29.04 .2017 & 21.23 & 19.27 & 18.414 & -0.856 \\
\hline 24 & K25 & 644399 & 4084237 & 22.167 & 30.04 .2017 & 21.64 & 15.36 & 16.630 & 1.270 \\
\hline 25 & K26 & 643190 & 4084503 & 30.712 & 30.04 .2017 & 20.65 & 15.35 & 16.558 & 1.208 \\
\hline
\end{tabular}


Avşar, Kurtuluş

Çizelge 1. (devamı)

Table 1. (continued)

\begin{tabular}{|l|c|l|l|c|c|c|c|c|c|}
\hline 26 & K27 & 643176 & 4083673 & 31.528 & 30.04 .2017 & 20.97 & 15.33 & 16.606 & 1.276 \\
\hline 27 & K28 & 643937 & 4083666 & 28.668 & 30.04 .2017 & 21.07 & 15.30 & 16.534 & 1.234 \\
\hline 28 & K29 & 644426 & 4083064 & 26.089 & 30.04 .2017 & 21.16 & 15.36 & 16.630 & 1.270 \\
\hline 29 & K30 & 645701 & 4082755 & 11.448 & 29.04 .2017 & 21.06 & 15.19 & 17.558 & 2.368 \\
\hline 30 & K31 & 645710 & 4082043 & 5.625 & 29.04 .2017 & 20.87 & 19.95 & 18.771 & -1.179 \\
\hline 31 & K32 & 644964 & 4082271 & 20.328 & 29.04 .2017 & 21.22 & 15.23 & 16.439 & 1.209 \\
\hline 32 & K33 & 644835 & 4081528 & 10.122 & 29.04 .2017 & 21.49 & 15.40 & 16.129 & 0.729 \\
\hline 33 & K34 & 644000 & 4082322 & 26.679 & 30.04 .2017 & 21.42 & 15.33 & 16.630 & 1.300 \\
\hline 34 & K35 & 643349 & 4082984 & 31.025 & 30.04 .2017 & 20.72 & 15.38 & 16.558 & 1.178 \\
\hline 35 & K36 & 642526 & 4083532 & 31.924 & 30.04 .2017 & 21.09 & 15.41 & 16.606 & 1.196 \\
\hline 36 & SUB1 & 642408 & 4082821 & 27.665 & 30.04 .2017 & 21.07 & 15.34 & 16.344 & 1.004 \\
\hline 37 & SUB2 & 642676 & 4082773 & 26.299 & 30.04 .2017 & 20.90 & 15.36 & 16.511 & 1.151 \\
\hline 38 & SUB3 & 643831 & 4081711 & 21.025 & 30.04 .2017 & 20.76 & 15.43 & 17.368 & 1.938 \\
\hline 39 & SUBC-1 & 651289 & 4091105 & 1.742 & 30.04 .2017 & 20.21 & 20.21 & 19.508 & -0.702 \\
\hline 40 & SUBC-2 & 645999 & 4084040 & 2.111 & 29.04 .2017 & 21.12 & 21.03 & 19.270 & -1.760 \\
\hline
\end{tabular}

\section{BULGULAR}

\section{Su Ölçümleri}

Öncel çalışmalarda da belirtildiği gibi, Köyceğiz Gölü güney ve kuzeyde iki ayrı çanaktan oluşmaktadır. Gölün orta kısmında, su derinliğini 2 metreye kadar düşüren bir sirt, bu iki çanağ1 birbirinden ayırmaktadır. Köyceğiz Gölü’nün, CTD (Conductivity-TemperatureDepth) cihazının derinlik verisi ile oluşturulan batimetri haritası incelendiğinde, kuzey çanağın en derin noktasının $24 \mathrm{~m}$ civarında, güney çanağın ise en derin yerinin $32 \mathrm{~m}$ civarında olduğu belirlenmiştir (Şekil 2).

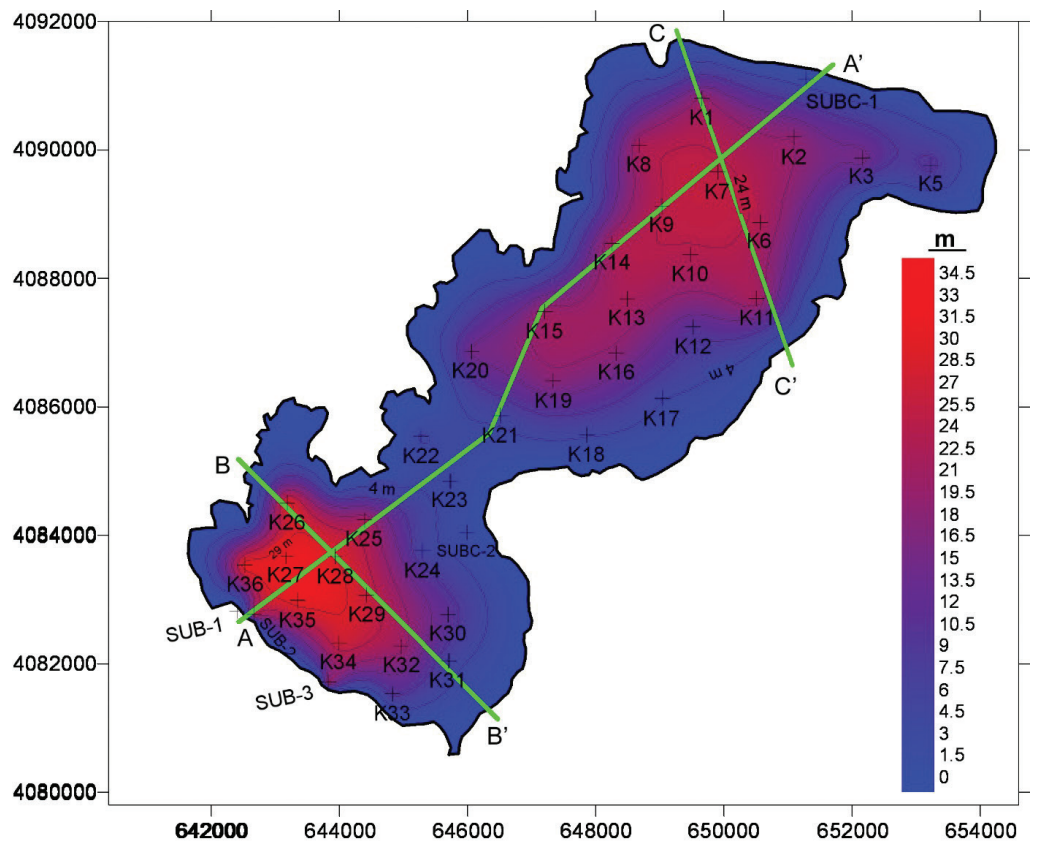

Şekil 2. Batimetri haritası.

Figure 2. Bathymetry map. 
Şekil 3a'daki Su Sıcaklığı - Derinlik grafiği incelendiğinde, kuzey ve güney çanaklarda gölün suyunun termal olarak tabakalandiğ 1 , tabanda ve yüzeyde farklı sıcaklıkta iki su tabakasının bulunduğu ve bu tabakaların sinırının yüzeyden yaklaş1k $8 \mathrm{~m}$ derinde olduğu gözlemlenmektedir. $\mathrm{Bu}$ sınır, kuzey çanakta daha keskindir. Güney çanakta ise, yaklaşık 7 metre kalınlıkta bir geçiş zonundan sonra alttaki tabakaya geçilmektedir. Su Sicaklığg - Derinlik grafiğinde gözlemlenen bir diğer husus ise, alt ve üst tabakaların sıcaklıklarının çanaktan çanağa farklılık göstermesidir. Kuzey çanakta üstteki tabakanın sıcaklığ genellikle $17.8 \mathrm{C}^{\text {o }}$ ile $19.1 \mathrm{C}^{\mathrm{o}}$ arasında değişirken, alttaki tabakanın sıcaklığ 11.3
$\mathrm{C}^{\circ}$ ile $13.4 \mathrm{C}^{\circ}$ arasında değişmektedir. Güney çanakta ise üstteki tabakanın sıcaklığı genellikle 19.7 $\mathrm{C}^{\circ}$ ile $21.0 \mathrm{C}^{\circ}$ arasında değişirken, alttaki tabakanın sıcaklığı $15.3 \mathrm{C}^{\circ}$ civarındadır. $\mathrm{Bu}$ veriler 1şığında güney çanaktaki su sıcaklığının kuzey çanağa göre her iki tabaka için de yüksek olduğu söylenebilir. Sıcaklık dağılımı ile ilgili diğer önemli bir nokta ise kuzey çanağın güney kısmında gerçekleştirilen ölçümlerle ilgilidir. K12'den K21'e kadar olan noktaları kapsayan bu ölçümlerde yüzeye yakın sıcaklıklar güney çanağın üst kısmındaki sıcaklıklarla benzerlik göstermektedir. $\mathrm{Bu}$ durum güney çanağın üst tabakasının ortadaki sırtı aşarak kuzeye doğru bir miktar ilerlediğini göstermektedir.

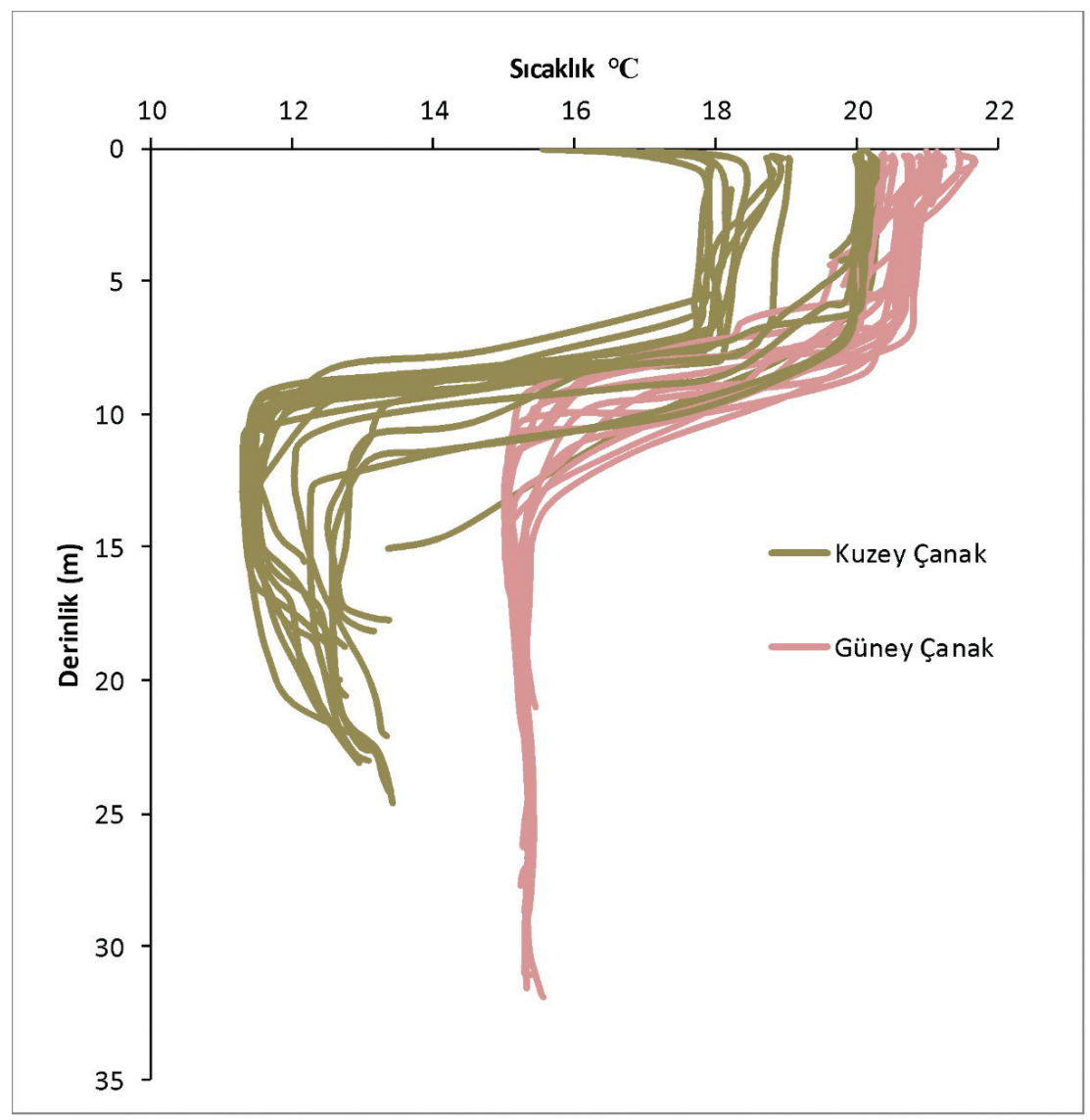

Şekil 3. a. Derinlik - sıcaklık grafiği.

Figure 3. a. Depth vs. temperature graph. 
Avşar, Kurtuluş

$\mathrm{Bu}$ araştırmada öncelikle göl suyu ve sediman sicaklıklarının alansal/hacimsel değişimine odaklanılmıştır. Bununla birlikte EC (düzeltilmemiş, su sıcaklığındaki değerler) ve $\mathrm{pH}$ gibi parametreler de ölçülmüştür. EC Derinlik grafiği incelendiğinde her iki çanakta da üst tabakanın kalınlığının $7 \mathrm{~m}$ olduğu söylenebilir (Şekil 3b). Her iki çanakta da $5 \mathrm{mS}$ / $\mathrm{cm}$ civarında sabit bir EC gözlemlenmektedir. $\mathrm{Bu}$ derinliğin altında kuzey çanak sularının EC'si sabit bir eğimle düşüm gösterirken, güney çanak suları yine yaklaşık 7 m'lik bir geçiş zonu sergilemekte, bu zonun altında $13 \mathrm{mS} / \mathrm{cm}$ civarında sabit bir değere ulaşmaktadır. Güney çanakta $27 \mathrm{~m}$ derinlikten sonra, EC değerlerinde $2 \mathrm{mS} / \mathrm{cm}$ seviyelerine hafif bir yükseliş eğilimi gözlemlenmektedir. Suyun EC'sinin sıcaklık artışıyla beraber arttığı bilinmektedir. Köyceğiz Gölü'nde derine indikçe sıcaklığın düşmesine rağmen EC'nin artması, altta ve üste toplam çözünmüş madde miktarı birbirinden tamamen farklı su fasiyeslerinin bulunduğunu göstermektedir. $\mathrm{pH}$ - Derinlik grafiğinde, üst tabakanın kalınlığının $8 \mathrm{~m}$ civarında olduğu görülmektedir (Şekil 3c). Üst tabakada yine kuzey çanak suları 8.35 civarında sabit bir $\mathrm{pH}$ değeri sergilerken, güney çanak üst tabaka suları 8.5 civarında sabit bir değer sergilemektedir. 8 $\mathrm{m}$ derinliğin altında kuzey çanakta $\mathrm{pH}$ değeri düzgün bir eğimle 7.6 değerine doğru azalma eğilimine girmekte, güney çanakta yaklaşık 8 m'lik bir geçiş zonundan sonra 7.45 civarında sabitlenmektedir.

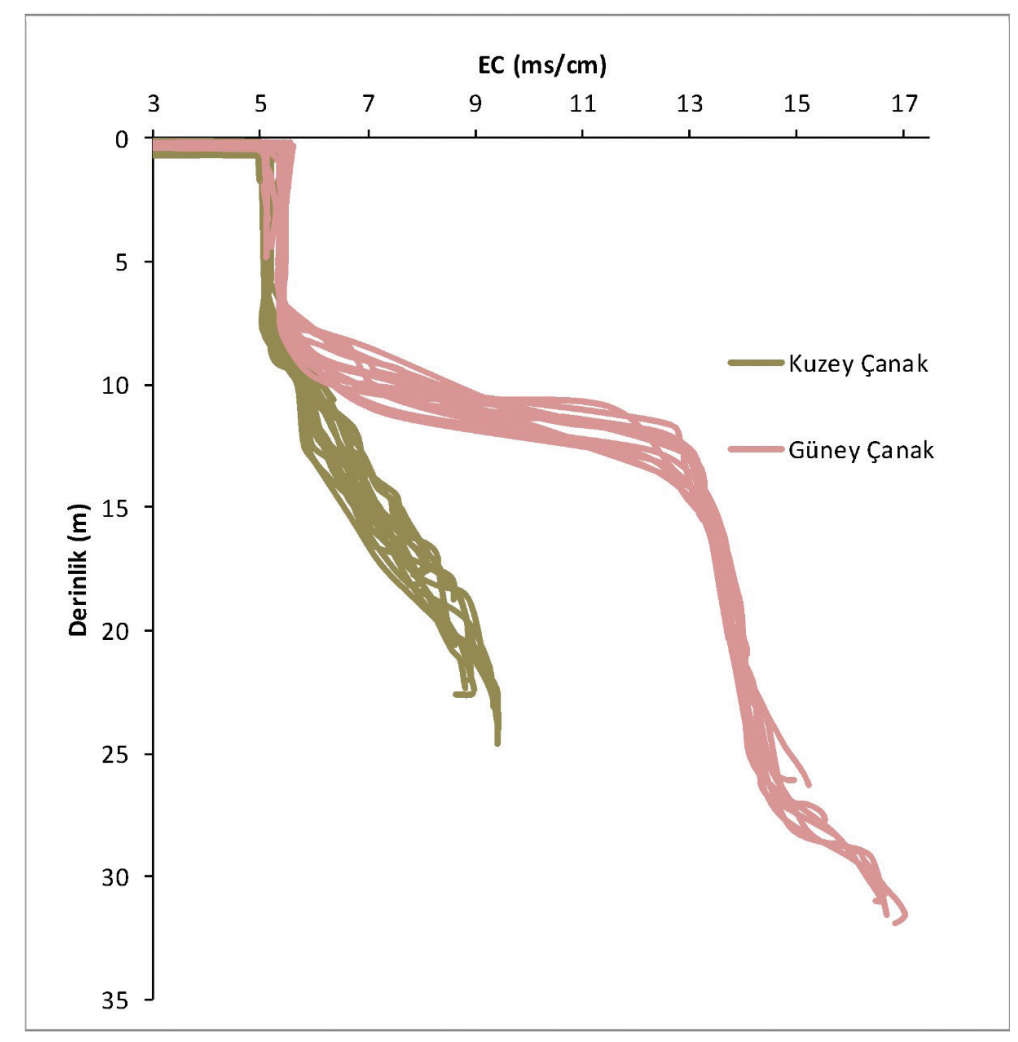

Şekil 3. b. Derinlik - EC grafiği.

Figure 3. b. Depth vs. EC graph. 


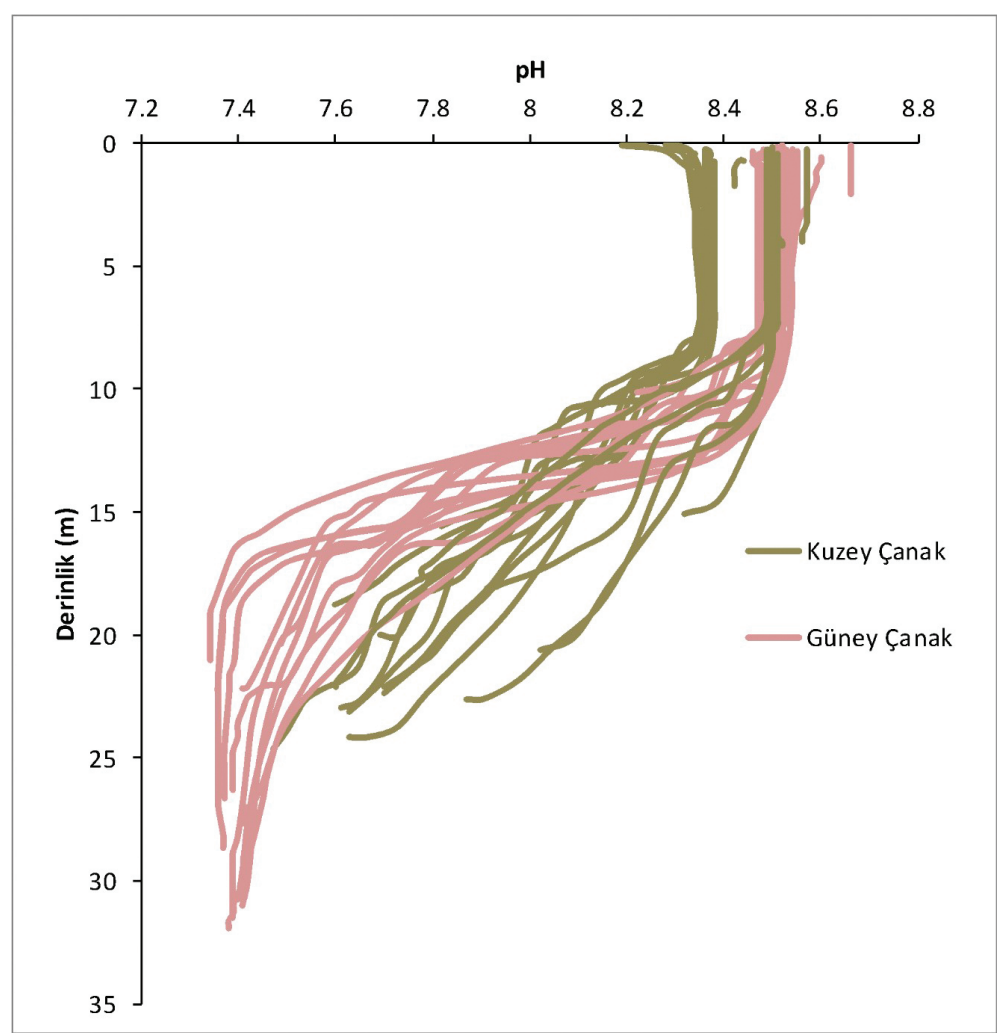

Şekil 3. c. Derinlik - pH grafiği.

Figure 3. c. Depth vs. pH graph.

$\mathrm{Su}$ sıcaklığının alansal dağglımını gözlemlemek için, her bir ölçüm noktasından gelen/ölçülen dikine profillerden, yüzeyde ölçülen sicaklığın ve en derin noktada ölçülen su sıcaklığının alansal dağılım haritaları hazırlanmıştır (Şekil 4). Bu haritalar incelendiğinde, sıcaklıklar çanakların içinde sabitken, iki ayrı çanak içindeki suların sıcaklıkları hem derindeki hem de yüzeydeki tabakada farklılık göstermektedir. Başka bir deyişle, kuzey çanaktaki su, güney çanaktaki sudan daha soğuktur. Şekil 3'te verilen Sıcaklık Derinlik grafiğinde de gözlemlenen, güney çanak üst tabaka suyunun kuzeye doğru bir miktar ilerlemesi durumu, yüzey suyu sıcaklığı dağılım haritasında da açıkça gözlemlenmektedir. Her iki çanağın alt tabakalarında birbirleriyle bir etkileşim gözlemlenmemiştir. Yüzey ve taban suyu sıcaklık dağılım haritasında gözlemlenen bir diğer husus da; gölün kuzey sınırında bulunan SUBC-1 isimli sualtı soğuk su kaynağı etrafında pozitif sıcaklık anomalisi varken, diğer sualtı kaynaklarının (SUB-1, SUB-2, SUB-3, SUBC2) etrafinda pozitif veya negatif herhangi bir belirgin anomali gözlemlenmemiş olmasıdır. $\mathrm{Bu}$ durum aşağıdaki bölümlerde tartışılmaktadır.

Köyceğiz Gölü suyunun fiziksel ve kimyasal özelliklerini üç boyutlu olarak algılayabilmek için, alansal dağılım haritalarına ek olarak 3 adet kesit hazırlanmış ve Şekil 5'te sunulmuştur. Bu kesitler incelendiğinde her iki çanakta da iki adet tabaka gözlemlenmektedir. Üst tabakanın 
Avşar, Kurtuluş

alt sınırı yüzeyden 7-9 m derinliktedir. Daha önce Derinlik - Sicaklık grafiğinde gözlemlenen tabakalanmanın geometrisi ve iki çanak arasındaki farklılıklar, bu kesitlerde daha belirgindir. Kesitlerden de görüleceği üzere, kuzey çanaktaki alt ve üst tabakalar güney çanağa göre daha soğuktur. Bu kesitlerden özellikle
AA' hattı boyunca alınanlarda gözlemlenen en çarpıcı nokta, kuzey ve güney çanaklarda suların fiziksel özelliklerinin genellikle birbirinden farklı olmasına rağmen, güney çanağın üst tabakasındaki suyun ortadaki sırtı aşıp kuzey çanağın güneyine doğru yerleşmiş olmasıdır.

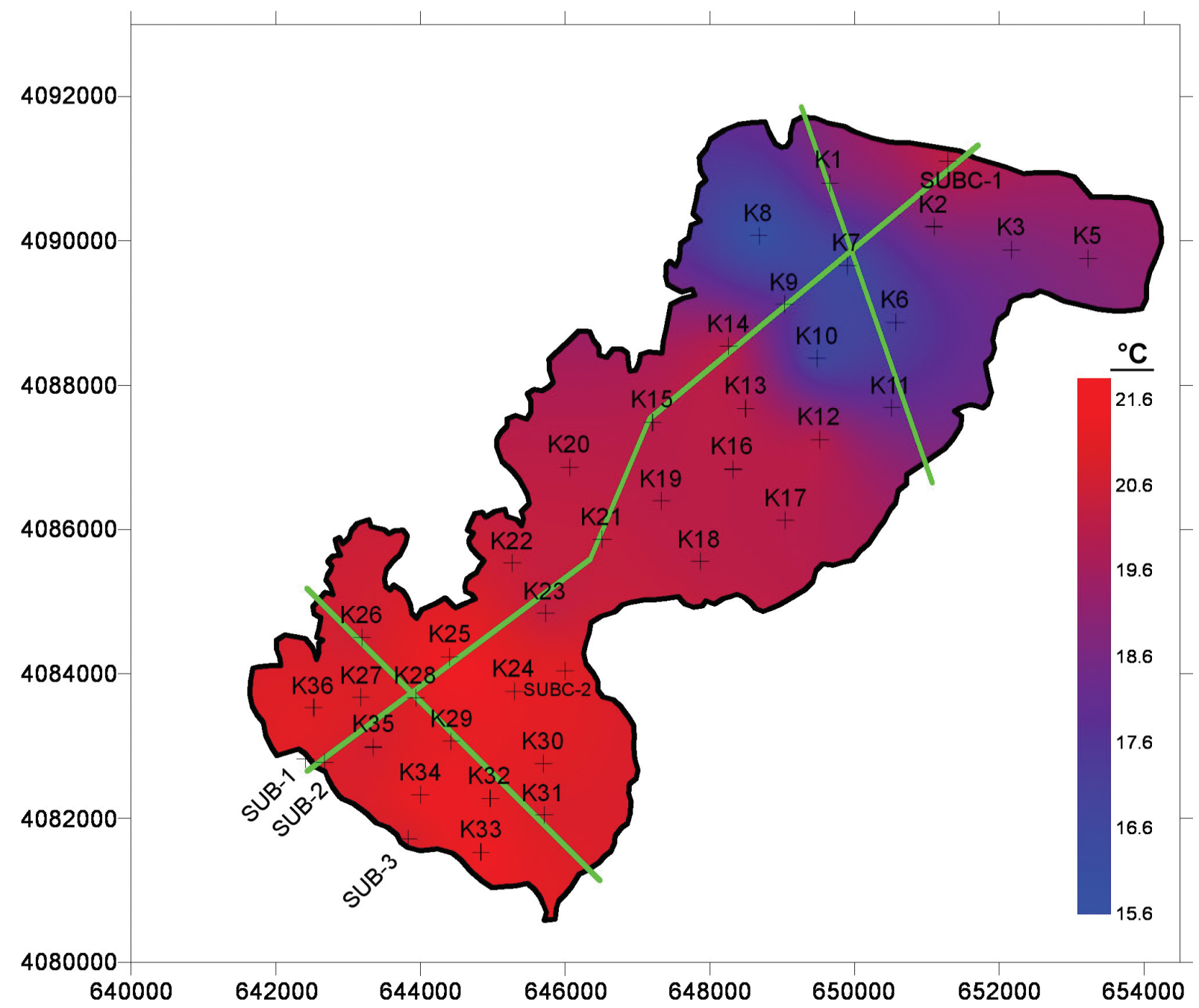

Şekil 4. a. Yüzey suyu sıcaklığı dağılım haritası.

Figure 4. a. The temperature distribution map of the surface water. 


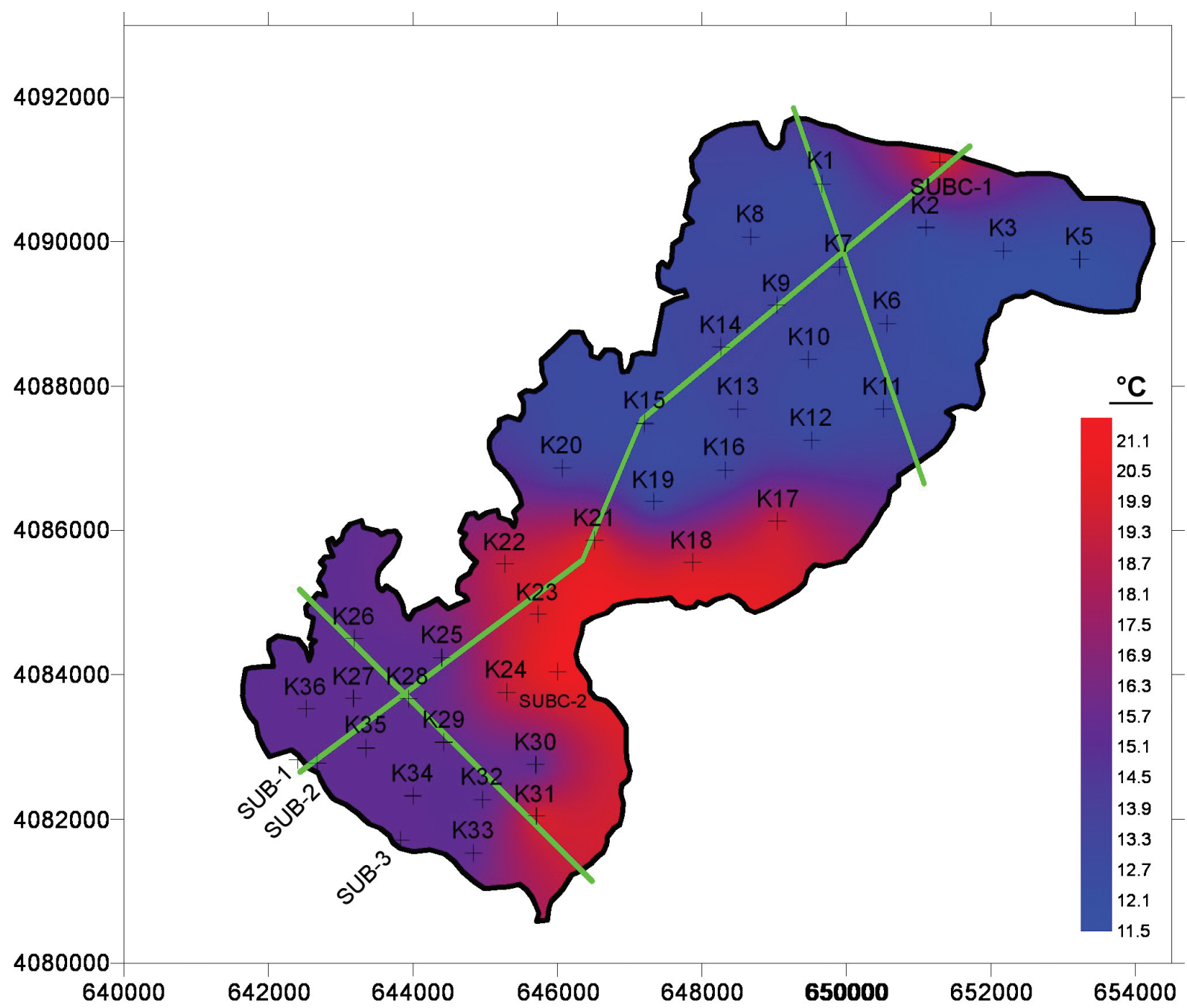

Şekil 4. b. Taban suyu sıcaklığı dağılım haritası.

Figure 4. b. The temperature distribution map of the bottom water. 
Avşar, Kurtuluş
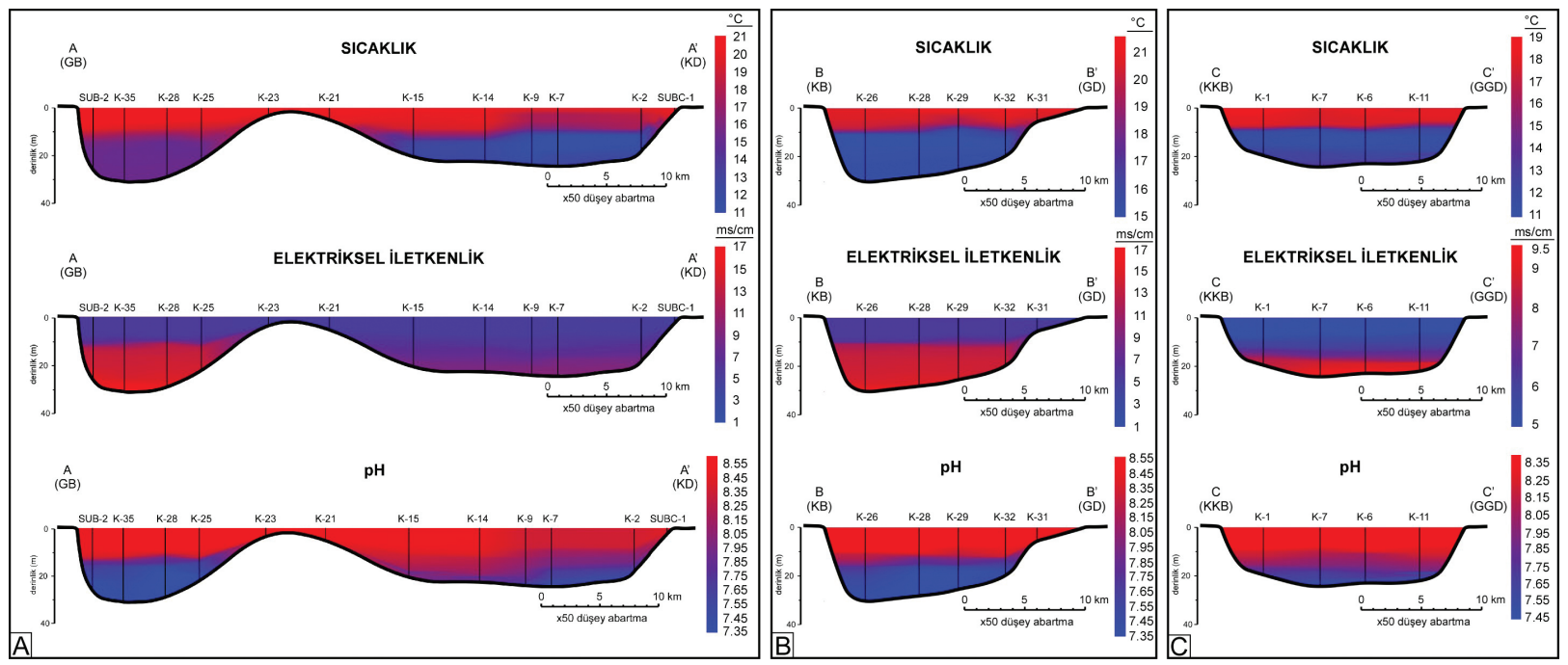

Şekil 5. Sicaklık, elektriksel iletkenlik, ve pH kesitleri a) AA', b) BB', c) CC'.

Figure 5. Temperature, electrical conductivity and $p H$ cross sections a) $\left.A A^{\prime}, b\right) B B^{\prime}$, c) $C C^{\prime}$.

\section{Sediman Ölçümleri}

Ölçüm noktalarında Termoprob Cihazı ile ölçülen taban sediman sıcaklıkları Çizelge 1 'de verilmiştir. $\mathrm{Bu}$ veriler aracılığı ile, göl tabanındaki sedimanların sicaklıklarının alansal dağılımını incelemek amacıyla alansal dağılım haritası oluşturulmuştur (Şekil 6). Bu harita incelendiğinde, göl suyunun sıcaklığında olduğu gibi, taban sediman sicaklığı da aynı çanak içinde genellikle benzer sıcaklık dağılımı sergilerken, çanaktan çanağa sicaklık değişmektedir. Ortalaması $17.12 \mathrm{C}^{\circ}$ olan güney çanağı taban sedimanlarının sıcaklığı, ortalamas1 $15.71 \quad \mathrm{C}^{\mathrm{o}}$ olan kuzey tabanı sedimanlarından daha sıcaktır. Göl tabanında bulunan soğuk su kaynaklarının etrafında bir s1caklık anomalisi gözlemlenmektedir ve bu kaynaklar etrafındaki sediman sıcaklıklarının, gölün diğer kısmındakilerden daha yüksek olduğu söylenebilir. Yine gölün güney kısmında bulunan sualtı sicak su kaynaklarından SUB-3, pozitif bir sicaklık anomalisi sergilerken; SUB1 ve SUB-2 kaynaklarında herhangi bir anomali gözlenmemektedir. Sualtı kaynaklarının, taban sedimanlarının ve göl suyunun sicaklıklarına etkisi Tartışma bölümünde irdelenecektir. 


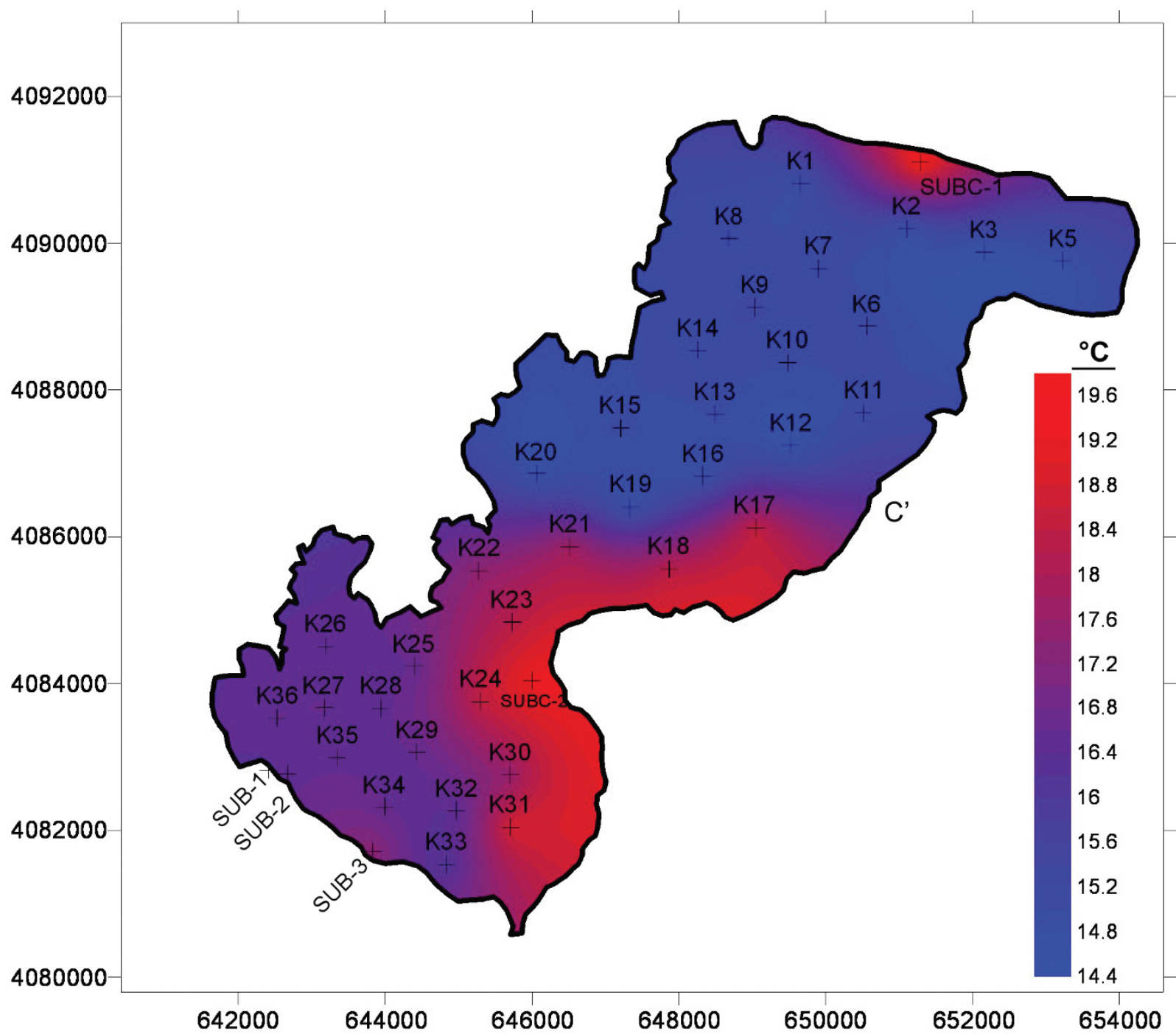

Şekil 6. Taban sedimanları sıcaklık dağılım haritası.

Figure 6. The temperature distribution map of the bottom sediments.

40 lokasyonda su ve sediman sicaklığında yapılan ölçümler, gölde 4 adet su kütlesinin bulunduğunu göstermiştir. Bunun yanı sıra, sediman sıcaklıkları da güney ve kuzey çanakta birbirinden farklı değerler vermektedir. Bu 4 adet su kütlesini ve iki farklı çanakta farklı sıcaklıklar sunan sedimanları, sayısal olarak daha iyi anlayabilmek için sıcaklık (su ve sediman), EC ve $\mathrm{pH}$ ölçüm sonuçlarının her bir kütle/alan için kutu diyagramları hazırlanmıştır (Şekil 7). Şekil 7 incelendiğinde, her iki çanaktaki taban sediman sıcaklıklarının, yüzey suyundan daha soğuk, taban suyundan daha sicak olduğu görülmektedir. Güney ve kuzey çanaktaki EC değerleri, üst tabakada daha düşük, alt tabakada ise daha yüksektir. Kuzey ve güney çanaklar karşılaştırıldığında, üst tabaka değerleri birbirine yakınken, alt tabakada güney çanak daha 
Avşar, Kurtuluş

yüksek değerler sergilemektedir. $\mathrm{pH}$ verilerine bakıldığında, her iki çanakta da üst tabaka, alt tabakaya göre daha yüksek değerler vermektedir. Üst tabakada, güney çanaktan kuzey çanağa geçildiğinde $\mathrm{pH}$ değeri düşmektedir. Çanakların alt tabakaları pH açısından karşılaştırıldığııda, kuzey çanağın daha yüksek pH değerine sahip olduğu görülmektedir.
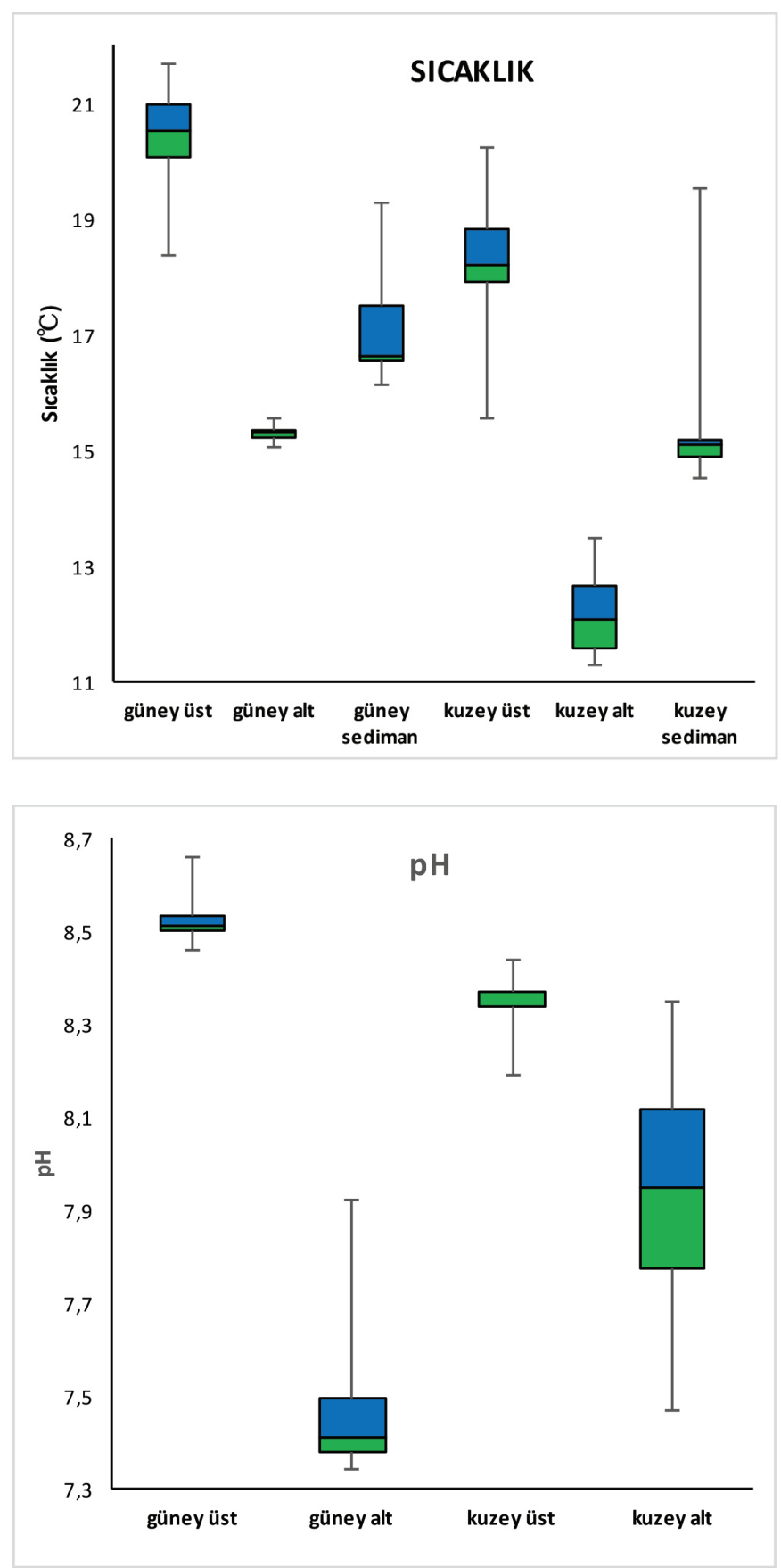


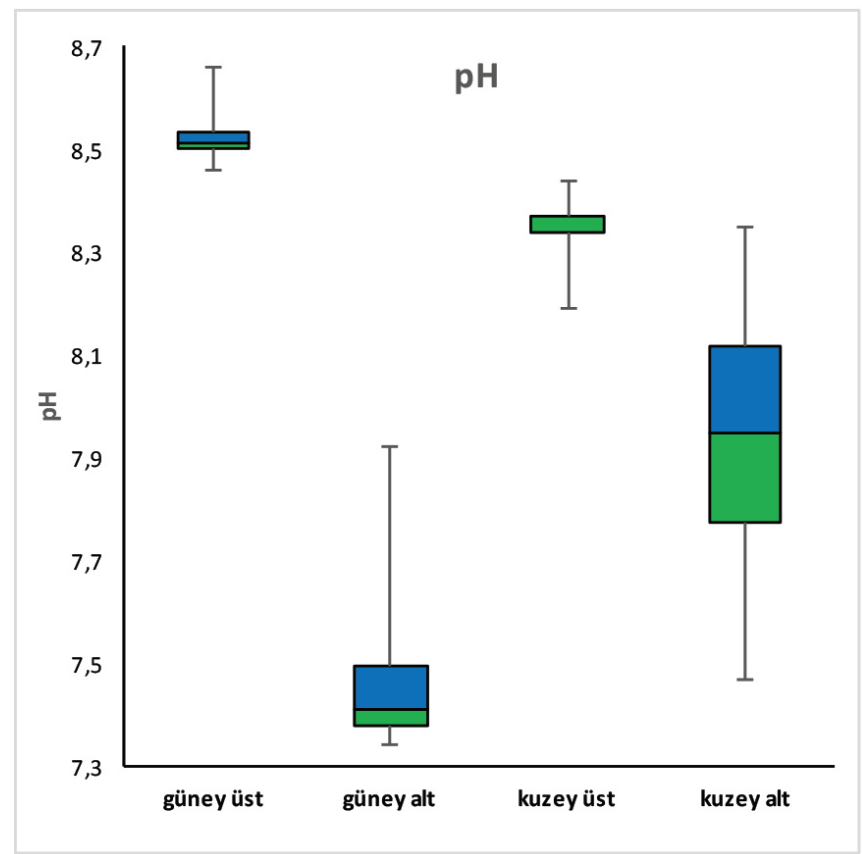

Şekil 7. Köyceğiz Gölü ölçümlerinin kutu diyagramları (mavi: medyan ve 75 persantil arasındaki değerleri, yeşil: 25 persantil ve medyan arasındaki değerleri, kutunun altına ve üstüne doğru uzanan çizgiler: sırasıyla en düşük ve en yüksek değerleri göstermektedir).

Figure 7. The box plots of the Lake Köyceğiz measurements (blue: the values between the median and the 75 percentile, green: the values between the 25 percentile and the median, lines below and above the box: the minimum and maximum values respectively).

\section{TARTIŞMA}

Bulgular kısmında belirtildiği gibi, Köyceğiz Gölü termal bir tabakalanma sergilemektedir. Bu tabakalanmanın yanı sıra bir diğer çarpıcı nokta ise, gerek göl suyunun gerekse taban sedimanlarının kuzey çanakta daha soğuk olduğudur. Taban sedimanları ile göl suyunun birbiriyle etkileşimini inceleyebilmek için, taban sedimanlarının sıcaklığından taban su sıcaklığg çıkarılmış, bulunan bu sonuçlar kullanılarak sıcaklık farkı alansal dağılım haritası hazırlanmıştır (Şekil 8). Bu haritada görülmektedir ki; her iki çanakta da sedimanlar gölün tabanındaki sudan yaklaşık $1.7 \mathrm{C}^{\circ}$ daha sicaktır ve bu fark her iki çanak için genellikle sabittir. İki çanak arasındaki nispeten sığ bölgede ise su sicaklığının taban sedimanlarının sıcaklığından daha yüksek olduğu gözlemlenmektedir. Bu durum göstermektedir ki; güney çanak sedimanları ve suları kuzey çanağa göre aynı oranda daha sıcaktır. Güney çanaktaki bu tutarlı sıcaklık, güneydeki Sultaniye Kaplıcaları, Delibey Girmesi, Kelgirme Kaynağ 1 ve sualtı sıcak su kaynakları ile sahada kendini gösteren jeotermal aktivite ile açıklanabilir. Sediman ve sulardaki bu paralel sıcaklık yükselmesi ya göle deşarj olan sıcak suların göl suyunu 1sitmasindan ya da halihazırda sicak olan taban kayaların, üzerindeki sedimanın ve dolayısıyla suyun sıcaklığını bir miktar arttırmasından kaynaklanmaktadır. Her iki durumda da, güneyde jeotermal kaynakların komşusu olan güney çanağın sediman ve su sıcaklığının kuzey çanağa göre bir miktar fazla olması jeotermal aktiviteyle tutarlı görünmektedir. Su altındaki ve karadaki 
Avşar, Kurtuluş

jeotermal kaynaklar, bulundukları bölgedeki su ve taban sedimanların sicaklığını genellikle noktasal olarak yükseltecek ve pozitif anomali verecek yönde etkilememektedir. Ancak, güney çanaktaki termal kaynakların zamana bağlı bir sıcaklık birikimiyle daha geniş alanlarda küçük sıcaklık yükselmelerine yol açtığı söylenebilir.
$\mathrm{Su}$ ve sediman sıcaklık ölçümleri ile ilgili dikkat çekici diğer bir bulgu, sualtı sıcak ve soğuk su kaynaklarının sediman ve su sicaklıklarına etkisidir. Sualtı sicak su kaynaklarından SUB3 yakınında taban sediman sicaklığı, yakın çevredeki diğer ölçümlere göre bir miktar

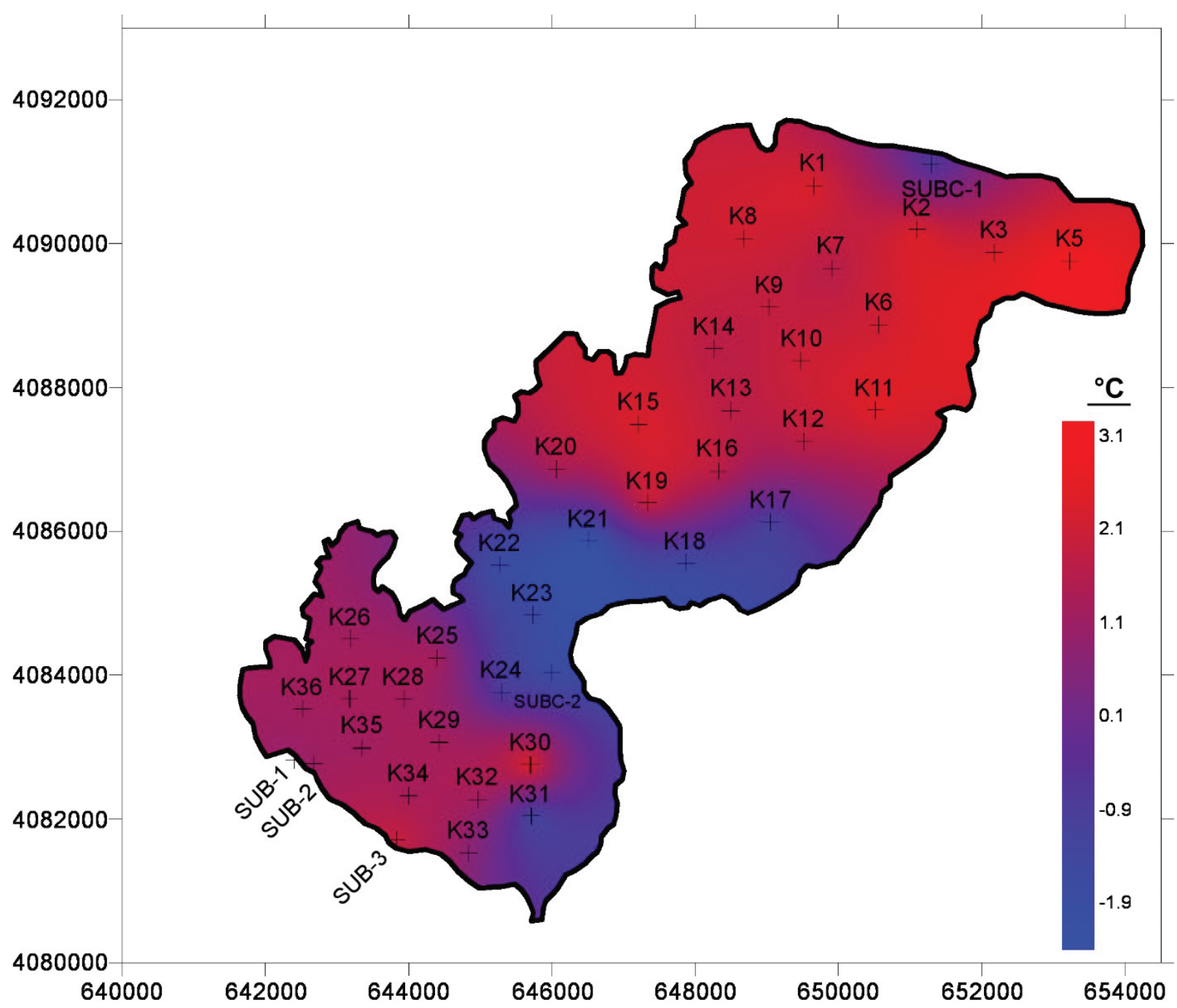

Şekil 8. Sediman sıcaklığı ile taban suyu arasındaki sıcaklık farkı dağılım haritası.

Figure 8. The distribution map of the temperature difference between sediments and bottom water. 
yüksektir (Şekil 6). Bu durum, kaynaktan çıkan suyun sedimanları 1sıtmasıyla açıklanabilir. SUB-3'deki çamur sıcaklığı ölçümü, kaynağın olduğu noktada tabanın kaya olması ve termoprobun saplanamamasindan dolayi tam olarak bu noktada değil, kaynağın yaklaşık $90 \mathrm{~m}$ kuzeyinde yapılmıştır. Dikey su sıcaklığg profili de yine bu noktadan alınmıştır. Bu noktada, su sıcaklığında bir anomali gözlenmeyip sediman sıcaklığında bir anomali gözlenmiştir. Bu durum göstermektedir ki, $90 \mathrm{~m}$ uzaktaki sedimanlar sualtı kaynağı tarafından 1sıtılmıştır. Ancak sualtı kaynağından çıkan sıcak su 90 m uzakta göl suyuyla karıştığından suda herhangi bir sıcaklık anomalisi vermemiştir (Şekil 4). Tabanın kaya olma durumu SUB-1 ve SUB-2'de de gözlemlenmiş, SUB-1'de 95 m kuzey doğudan, SUB-2'de 60 m kuzeyden ölçümler alınmıştır. Alınan bu ölçümlerde de, suda ve taban sedimanlarında herhangi bir sicaklık anomalisi gözlenmemiştir (Şekil 5). Bunun nedeni, gerçek kaynak noktası ile ölçüm alınan nokta arasındaki mesafenin, birbirinden etkilenmeyecek kadar çok olmasıdır.

Sualtı kaynak noktalarının çevresindeki sıcaklık anomalileri ile ilgili bir diğer ilginç konu, Avşar vd. (2017) tarafından soğuk sualtı kaynağ1 olarak tanımlanan SUBC-1 kaynağının etrafinda, hem sedimanlarda hem de sularda pozitif bir anomali görünmesidir (Şekil 4 ve Şekil 6). Soğuk sualtı kaynaklarının, göl suyu ve taban sedimanlarını soğutması ve bu noktaların etrafinda negatif bir sicaklik anomalisi oluşturması gerekirdi. Sualtı soğuk su kaynakları, Avşar vd. (2017) tarafından göl suyunun sicaklığının $20 \mathrm{C}^{\circ}$ 'nin üstünde olduğu yaz aylarında keşfedilmiş ve sıcaklığı göl suyundan düşük olduğu için soğuk su kaynağ 1 olarak kaydedilmiştir. Bu çalışmadaki ölçümler Nisan ayında yapıldığ 1 için, göl suyu sıcaklığg yaz aylarına göre düşüktür ve çıkış sıcaklığı nispeten sabit olan sualtı kaynağı bu ölçümde pozitif bir sıcaklık anomalisine sebep olmuştur.

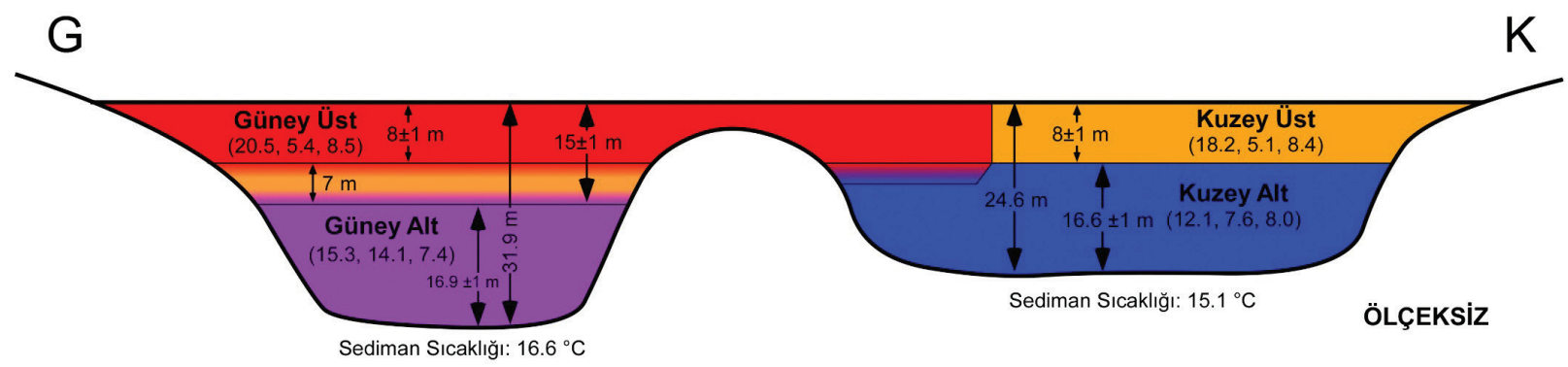

Şekil 9. Köyceğiz Gölü’nün taslak kesiti (Ölçeksiz. Parantez içindeki değerler sırasıyla sıcaklık $\left(\mathrm{C}^{\circ}\right), \mathrm{EC}(\mathrm{mS} / \mathrm{cm}) \mathrm{ve} \mathrm{pH}$ ölçümlerinin medyan değerleridir. Taban sediman sıcaklık değerleri medyan değerleridir).

Figure 9. Sketch cross section of the Lake Köyceğiz (Not to scale. The values in the parenthesis are the median values of temperature $\left({ }^{\circ} \mathrm{C}\right), \mathrm{EC}(\mathrm{mS} / \mathrm{cm})$ and $\mathrm{pH}$ respectively. Bottom sediment temperature values are medians). 
Avşar, Kurtuluş

\section{SONUÇ}

Çalışma sonucunda elde edilen bütün veriler birlikte değerlendirilerek Şekil 9'da sunulan taslak kesit oluşturulmuştur. $\mathrm{Bu}$ çalışmadan çıkarılan sonuçlar aşağıdaki gibidir:

- Kuzey ve güneyde olmak üzere gölde iki farklı çanak bulunmaktadır. Kuzeydeki çanağın ölçülen en derin yeri $24.6 \mathrm{~m}$ iken güney çanağın en derin yeri 31.9 m'dir. Göldeki su ve sediman sicaklıkları iki çanakta da farkl11ık göstermektedir.

- 40 noktada yapılan dikey sicaklık, EC, ve $\mathrm{pH}$ ölçümleri gölde fiziksel özellikleri birbirinden farklı iki yatay su tabakası bulunduğunu göstermektedir. $\mathrm{Bu}$ yatay su tabakaları, güney ve kuzey çanakta birbirinden farklı fiziksel özellikler sunduğu için, gölde birbirinden farklı dört adet su kütlesi tanımlanmıştır.

- Kuzey çanakta üstteki tabakanın sıcaklığ 15.6 $\mathrm{C}^{\circ}$ ile $20.2 \mathrm{C}^{\text {o }}$ arasında değişiyorken, alttaki tabakanın sıcaklığı $11.3 \mathrm{C}^{\circ}$ ile $13.5 \mathrm{C}^{\circ}$ arasında değişmektedir.

- Güney çanakta üstteki tabakanın sıcaklığ1 $18.4 \mathrm{C}^{\circ}$ ile $21.7 \mathrm{C}^{\circ}$ arasında değişiyorken (medyan: 20.5), alttaki tabakanın sicaklığ1 genellikle $15.3 \mathrm{C}^{\circ}$ civarındadır.

- Üst tabakanın tabanı her iki çanakta da $8 \pm$ $1 \mathrm{~m}$ derinliktedir. Güney çanakta iki tabaka arasında yaklaşık $7 \mathrm{~m}$ kalınlığında bir geçiş zonu vardır. Kuzey çanakta ise geçiş zonu yoktur ve değerler sert bir şekilde değişmektedir. Güney çanaktaki üst tabaka, ortada iki çanağ1 ayıran sırtı/yükseltiyi aşıp kuzey çanağa doğru hücum etmiştir. Alt tabakanın kalınlığı her iki çanakta da yaklaşık 17 m'dir.
- Kuzey çanaktaki taban sedimanlarının sicaklığı (medyan: 15.1 $\mathrm{C}^{\circ}$ ), güney çanak sedimanlarının sıcaklığından (medyan: 16.6 $\mathrm{C}^{\circ}$ ) daha düşüktür.

- Sedimanların ve suların sicaklıklarına bakıldığında güney çanakta hem sedimanların hem de suların sicaklıkları (her iki tabaka için de) daha yüksektir. Bu durum, güneyde Sultaniye Kaplıcaları, Delibey Girmesi, Kelgirme ve sualt termal kaynaklar ile açığa çıkan jeotermal aktiviteyle açıklanabilir.

- Göl tabanındaki suyun sıcaklığı taban sedimanlarının sicaklığ 1 ile karşılaştırıldığında, her iki çanakta da taban sedimanlarının, hemen üzerindeki sudan bir miktar daha sıcak olduğu gözlemlenmektedir. Ortadaki sırttan alınan ölçümlerde ise, su sıcaklığının sediman sıcaklığından daha yüksek olduğu görülmüştür.

- Sualt1 kaynaklardan SUB-3 taban sedimanı sicaklığını, SUBC-1 ise hem göl suyu sıcaklığını hem de taban sediman sıcaklığın arttırarak, çevrelerinde pozitif bir sicaklık anomalisi oluşmasına neden olmaktadırlar.

- $\quad \mathrm{Bu}$ çalışma, göl suyu ve taban sedimanları sıcaklığına odaklansa da, EC ve $\mathrm{pH}$ değerleri de ölçülmüștür. Ölçülen bu veriler analiz edildiğinde, $\mathrm{EC}$ değerlerinin her iki çanaktaki üst tabakada $5 \mathrm{mS} / \mathrm{cm}$ civarındayken, alt tabakada bir miktar yükselerek güneyde 14.1 kuzeyde ise $7.6 \mathrm{mS} / \mathrm{cm}$ medyan değerine ulaştığ 1 görülmektedir. $\mathrm{pH}$ verileri ise, üst tabakada 8.5 , alt tabakada güneyde 7.4 kuzeyde 8.0 değerine ulaşmaktadır.

- Sicaklık, EC ve pH parametrelerine ilişkin değerler ve yorumlar Nisan ayı verileri sonuçlarıdır. 


\section{KATKI BELIRTME}

Yazarlar, arazi çalışmalarına katılan Recep Karakaya'ya teşekkür eder. $\mathrm{Bu}$ çalışmadaki ölçümler, 112Y137 numaralı TÜBİTAK projesi kapsamında alınan CTD ve Termoprob Cihazı ile gerçekleştirilmiştir.

\section{KAYNAKLAR}

Avşar, Ö., Avşar, U. Arslan Ş., Kurtuluş, B., Niedermann, S., Güleç, N., 2017. Subaqueous hot springs in Köyceğiz Lake, Dalyan Channel and Fethiye-Göcek Bay (SW Turkey): Locations, chemistry and origins. Journal of Volcanology and Geothermal Research. http://dx.doi. org/10.1016/j.jvolgeores.2017.07.016

Avşar, U., Jónsson, S., Avşar, Ö., Schmidt, S., 2016. Earthquake-induced soft-sediment deformations and seismically amplified erosion rates recorded in varved sediments of Köyceğiz Lake (SW Turkey). Journal of Geophysical Research Solid Earth, 121, 4767-4779, doi:10.1002/2016JB012820.

Bayarı, C. S., Kazancı, N., Koyuncu, H., Çağlar, S. S., Gökçe, D., 1995. Determination of the origin of the waters of Köyceğiz Lake, Turkey. Journal of Hydrology, 166, 171-191.

Bozkurt, E., Park, R. G., 1999. The structure of the Palaeozoic schists in the Southern Menderes Massif, western Turkey: a new approach to the origin of the main Menderes Metamorphism and its relation to the Lycian nappes. Geodinamica Acta, 12, 25-42.

Ertürk, A., 2002. Köyceğiz-Dalyan Lagün Sistemi'nin hidrolik modellenmesi. İstanbul Teknik Üniversitesi Fen Bilimleri Enstitüsü, İstanbul, Yüksek Lisans Tezi, 178 s (yayımlanmamaış).

Ertürk, A., Ekdal, A., Gürel, M., Karakaya, N., Cüceloğlu, G., Gönenç, E., 2017. Model-based assessment of groundwater vulnerability for the Dalyan Region of southwestern Mediterranean Turkey. Regional Environmental Change, 17 (4), 1193-1203.
Ertürk, A., Ekdal, A., Gürel, M., Karakaya, N., Güzel, C., Gönenç, E., 2014. Evaluating the impact of climate change on groundwater resources in a small Mediterranean watershed. Science of the Total Environment, 499, 437-447.

Golden Software Inc., 2012. Surfer 10 versiyonu. Golden, Inc., CO 80401 USA.

Gökgöz, A., Tarcan, G., 2006. Mineral equilibria and geothermometry of the Dalaman-Koycegiz thermal springs, southern Turkey. Applied Geochemistry, 21, 253-268.

Hinsbergen, D. J. J., 2010. A key extensional metamorphic complex reviewed and restored: The Menderes Massif of western Turkey. EarthScience Reviews, 102, 60-76.

Hinsbergen, D. J. J., Dekkers, M. J., Bozkurt, E., Koopman, M., 2010. Exhumation with a twist: paleomagnetic constraints on the evolution of the Menderes metamorphic core complex (western Turkey). Tectonics, 29, 1-33.

Kazanc1, N., Girgin, S., 2001. Physico-chemical and biological characteristics of thermal springs in Köyceğiz and Dalaman basins in southwestern Turkey and recommendations for their protection. Water Science and Technology, 43 (5), 211-221.

Kazancı, N., Plasa, R. H., Neubert, E., İzbırak, A., 1992. On the limnology of Lake Köyceğiz (SW Anatolia). Zoology in the Middle East, 6 (1), 109-126.

Rimmelé, G., Jolivet, L., Oberhansli, R., Goffe, B., 2003a. Deformation history of the high-pressure Lycian nappes and implications for tectonic evolution of SW Turkey. Tectonics, 22, 10071027.

Rimmelé, G., Oberhänsli, R., Goffé, B.,1, Jolivet, L., Candan, O., Çetinkaplan, M., 2003b. First evidence of high-pressure metamorphism in the "Cover Series" of the southern Menderes Massif. Tectonic and metamorphic implications for the evolution of SW Turkey. Lithos, 71, 19-46.

Şenel, M., 1997. 1:100000 Ölçekli, Türkiye Jeoloji Haritaları Serisi. No. 1, Jeoloji Haritası Fethiye L7 paftasi. Maden Tetkik ve Arama Genel Müdürlüğü, Jeoloji Etütleri Dairesi, Ankara, 30 s. 
Avşar, Kurtuluş

Sözbilir, H., Sarı, B., Uzel, B., Sümer, Ö., Akkiraz, S., 2011. Tectonic implications of transtensional supradetachment basin development in an extension-parallel transfer zone: the Kocaçay Basin, western Anatolia, Turkey. Basin Research, 23, 423-448.
Ten Veen, J. H., Boulton, S. J., Alçiçek, M. C., 2009. From palaeotectonics to neotectonics in the Neotethys realm: the importance of kinematic decoupling and inherited structural grain in SW Anatolia (Turkey). Tectonophysics, 473, 261281. 